\title{
Legal criteria for distinguishing between the subject and the object in the procedure for editing the human genome
}

\author{
Victoria Odintsova* \\ Department of International and European Law, Ural State Law University, 620137, Ekaterinburg, Russian Federation
}

\begin{abstract}
In this article, the author attempts to differentiate between the object and the subject in human genome editing procedures. The criteria for such distinction are individualization, passive capacity, active capacity and free will. The status of the embryo was analysed, since then the child is considered to have been born when the subject acquires the right to life. The reference is made to international instruments and to the case law of the European Court of Human Rights. Special attention is paid to the legality of biomedical research involving embryos in vivo and in vitro, as well as to the purposes of such intervention. As a key criterion for distinguishing between the object and the subject, the author emphasizes the existence of his free will. This criterion is reflected in one of the key principles applied to medical intervention and the existence of voluntary written consent to be manipulated. By distinguishing between object and subject, by means of identified criteria, it will be possible to ensure adequate protection of human rights and freedoms during the editing of the genome at the international and national levels.
\end{abstract}

\section{Introduction}

Experiments to edit the human genome, one of the aims of which is to improve the quality of human life, are gaining increasing popularity in the scientific community today. This is due, in particular, to the fact that in 2003, the U.S.A. completed the project «Human Genome», during which it was possible to completely decode the human gene, which served as a basis for further research in this field.

The rapid development of the genetic sciences requires the development and improvement of legal regulations in this area, both at the national and international levels.

The difficulty in drafting the relevant legal instruments arises from the fact that many issues, such as the editing of the human genome, lie at the intersection of law, medicine, ethics and need to be fully addressed.

The main objective is to fill existing gaps in international legal regulation in the application of genetic technologies. This can be achieved through the adoption of relevant international treaties.

The following achievements should also be highlighted:

- in 2013, the project «Human brain project» was launched in Switzerland with the main goal of creating the world's first human brain model;

- in 2016, the «Darpa» project was launched in the United States, dedicated to the design of neural networks;

- in 2016, for the first time in human history, viable embryos were tested in the UK.
On the one hand, the development of genetic technologies has made it possible to improve the quality of life of the population by applying previously patented methods for the treatment and early diagnosis of various diseases. However, at the same time, the application of genetic modifications has led to massive violations of the rights of individuals, in particular the right to privacy and many others.

In 2018, the first scientist to edit the embryo genome was biophysicist He Jiankui. He edited the twins' genome to make them immune to HIV, as one parent had a disease that could potentially be transmitted to future children. This experiment was not taken unequivocally as such intervention is prohibited.

The main human rights issue in the application of genetic technology is the editing of the embryo genome line. The problem is that there is no consensus on working with viable embryos.

For example, in Germany, Italy and Switzerland, embryo research is completely prohibited. In Australia, Canada, embryo research is not prohibited, but only offthe-shelf IVF embryos (embryos that have been created for reproductive purposes and will not continue to be used) may be used for such research. While in some states in the United States, embryos may be an object for research [1].

The legislation of Belgium, Italy and Mexico allows interventions that have a positive therapeutic effect on the embryo. The French Civil Code prohibits clinical research on embryos, except for those aimed at preventing or treating genetic diseases.

According to Canada's Artificial Human Reproduction Act, modification of an embryo is 
prohibited if it may in the future lead to irreversible changes in subsequent generations.

The Convention for the Protection of Human Rights and Dignity of the Human Being with regard to the Application of Biology and Medicine (Convention on Human Rights and Biomedicine (hereinafter referred to as the Oviedo Convention)) provides that genetic interference can only be performed in prophylactic for diagnostic or therapeutic purposes. And thereafter it will not change the genes of the heirs (Article 13) [2]. The article thus identifies the prerequisites for intervention in the human genome.

Yudin B. G. identifies possible errors during procedures that may lead to further mutations as problems in human genome editing technologies, and how these technologies will affect further offspring of an embryo that has already been edited [3].

In the process of applying human genome editing procedures, a large number of questions arise, one of which is the problem of distinguishing between the object and the subject of such editing. This distinction is necessary first of all to define the specific rights of the subjects and the mechanisms for their protection. This is primarily due to situations of unsuccessful intervention in the human genome, which later leads, for example, to health problems of a child born later. Is there a violation of the right to health? The answer to this question depends on whether the object or subject of the legal relationship is the edited embryo.

It should be noted that this is a different kind of relationship. In this regard, it is worth considering the similarities that are emerging in the development of research. For example, advances in science and technology have led to the emergence of robots, which some scientists view as civil rights objects in terms of civil law [4]. There are opinions that genes are related to intellectual property objects [5].

\section{Results and Discussion}

Before distinguishing between object and subject, it is necessary to separate the procedures performed with the human genome, namely sequencing the human gene and editing the embryo gene.

Sequencing the human genome is a «method for determining the order of nucleotides in the DNA of a molecule» [6]. Sequencing is often done with the DNA of an already-born person.

The gene is usually edited on a human embryo. The Model Law on the Protection of Human Rights and Dignity in Biomedical Research in the CIS Member States (hereinafter referred to as the CIS Model Law) permits biomedical research of embryos in vivo, but prohibits embryos in vitro (Article 2) [7]. The Oviedo Convention calls for proper protection of embryos in vitro in cases where research has been carried out with the authorization of the national legislation.

First of all, it is necessary to define what constitutes the object and the subject of a legal relationship.
The object of the legal relationship «is those phenomena (objects) of the world around us that are targeted by subjective legal rights and obligations» [8].

The subject of law «is a person who is a participant in public legal relations, who by his or her specificities may actually be a bearer of subjective legal rights and duties, who is actually able to participate in legal relations, the property of a subject of law by virtue of legal norms has become obsolete» [9].

S. I. Arhipov notes that «the concept of the subject of law is created by abstraction as a generalized image of reality, as a human legal mold, applied equally to the state, to the business organization and to the individual» [9].

S. S. Alexeyev emphasizes that the categories «subject of law» and «legal capacity» coincide in their content [8]. The legal personality in turn includes passive capacity and active capacity.

The criteria for distinguishing the object from the subject in genome editing are as follows:

- individualization;

- passive capacity;

- active capacity;

- free will.

It is the combination of the four above-mentioned criteria that will make it possible to distinguish between the object and the subject in the various processes of editing the human genome.

The individual is individualized by name. According to article 19, paragraph 1 , of the Civil Code of the Russian Federation (hereinafter referred to as the Civil Code), «citizens acquire and exercise rights and duties under their own name, including their surname and proper name, as well as patronymic...» [10]. Age and name separate individuals from each other [11]. Attention should be drawn to the need, in this case, to formalize a name, for example, by means of a birth certificate.

The embryo does not possess this characteristic for objective reasons. For example, a birth certificate is issued after the birth of a child.

Passive capacity «is the ability of a person to have subjective rights and legal obligations». Legal capacity arises from the moment of birth. This raises a legitimate question about the status of the embryo. G. F. Shershenevich noted that «not a fetus, but a born child influences legal relations» [12].

The Federal Law «On the Fundamentals of Protection of Health of Citizens in the Russian Federation» defines the moment of birth of the child as the moment of separation of the fetus from the body of the mother by delivery (Article 53) [13].

Some refer to embryos as preservatives of law and note that the closer a fetus is to a person (at the time of its birth) in its development, the more the right must see in it the future of its subject [9].

Turning to the practice of international judicial bodies, for example, the European Court of Human Rights (hereinafter referred to as the European Court) stated in its Judgment in the case «Parrillo v Italy» of 27 August 2015 that «embryos contain the applicant's 
genetic material and are an integral part of the applicant's genetic material» [14].

This position of the European Court was not clear and a number of judges, in particular Paulo Pinto de Albuquerque and Dmitry Dedov, expressed the opposite view in their judicial decisions.

Judge Paulo Pinto de Albuquerque notes that in this case the embryo cannot be considered as «property», as it is the «other person». He also notes the identity of the embryo and the child.

Judge Dmitry Dedov emphasizes that the embryo has the right to life and therefore the right to protection.

If we consider the embryo to be a full-fledged entity, what legal consequences would result from the birth of a dead child? To date, this event has not produced any legal effects.

From the foregoing, the legitimate question arises as to when an embryo acquires an autonomous status, if any, and when the subject has, for example, the right to life.

The European Court in the Decision in the case «Evans v United Kingdom» stated that «the embryo has no independent rights or interests and cannot claim the right to life» [15].

Thus, according to section 8.1 of the Law «On the Protection of Embryos» of Germany, an embryo is a «human egg, fertilized and capable of developing since the time of the fusion of the nuclei, as well as any totipotent cell removed from the embryo, which is able to divide and develop».

According to article 2 of the Federal Law «On Reproduction with Medical Assistance» of Switzerland, the embryo exists after the prevuclear synthesis.

Section 2 of the Law «On Fertilization and Human Embryology» of France defines an embryo as an egg which is in the process of fertilization or subjected to any other process which may lead to the emergence of an embryo.

It can thus be seen from the analysis of these normative acts that they do not give a legal characterization of the embryo, but only its medical characteristics and properties.

The American Convention on Human Rights links the creation of the right to life to the moment of conception [16]. The European Convention for the Protection of Human Rights and Fundamental Freedoms and the jurisprudence of the European Court assume that human life and the realization of the right to life arise from the moment of birth.

The national practice of States also differs on this issue. For example, the right to life from the moment of conception is recognized in Hungary, Abkhazia and Slovenia, while in Austria, Germany this right is realized from the moment of conception. Nevertheless, it is important to note that most States assume that the right to life arises from birth.

The Constitution of the Russian Federation guarantees the right to life (article 20) [17], but the basic law does not specify at what point the subject may exercise this right. The passive capacity of a person arises from the moment of birth (article 17 of the Civil Code). In addition, the Federal Law «On Fundamentals of Protection of Health of Citizens in the Russian Federation» enshrines the right of a woman to artificial termination of pregnancy. From this, it can be concluded that the legislator in the Russian Federation links the realization of a citizen's right to life to the moment of one's birth.

In practice, the question also arises as to who can turn to the judicial authorities to protect the interests of the embryo, for example, if its genome line has not been edited successfully, resulting in irreversible consequences in the form of any disease or abnormality.

At the present time, the issue remained unresolved in the international community, since the embryo had no autonomous status and, consequently, no one could defend its interests.

S. I. Arhipov emphasizes that «the starting point from which the existence of a legal person begins is traditionally recognized the moment of human birth» [9]. This also helps to eliminate legal uncertainty in the future, for example, when a stillborn child is born.

Active capacity refers «to the individual's ability to exercise subjective rights and legal obligations independently through his or her personal, conscious actions» [8]. As a general rule, full active capacity in Russia begins at the age of majority, that is, at the age of 18.

S. I. Arhipov defines dispositive active capacity as «the readiness (real ability, possibility) of a person in terms of the will, consciousness, organizational, property, other prerequisites, conditions for the exercise of the functions of a legal subject» [9].

A key feature of the distinction between subject and object in the human genome editing procedure is the existence of one's own free will. «It is the will that allows separating the subject from the object of the right and provides the opportunity to participate in legal relations».

Hegel stressed the inextricable link between guilt and will. He noted that «Will is guilty at all because the altered physical existence contains the predicate: mine» [18].

Willpower is also reflected in one of the key principles used in genome editing, namely, a voluntary written consent for the intervention. Article 5 of the Oviedo Convention lays down a general provision on the need for such consent in the event of a medical intervention. The Universal Declaration on Bioethics and Human Rights states that any medical intervention «must be carried out only with a prior, free and informed consent» (Article 6).

The need for such consent arises from issues arising in connection with the further processing and storage of information obtained through gene interference.

\section{Conclusion}

Advances in genetic sciences extend the frontiers of modern medicine and health care. The success of various genetic science projects during the 20th and 21st centuries accelerated the pace of genetic discovery and led to unprecedented technological innovations. The 
greatest number of projects in this area are related to human genome modifications. One of the main objectives of the modification of the human genome is to improve the quality of human life.

However, the rapid pace of development in the field of genetics raises a number of questions for the world community. One such issue is the legality of the intervention in the human genome and the further protection of human rights in connection with the intervention.

For the realization of human rights and the successful development of genomics science, it is important to look closely at emerging issues from various perspectives, including legislation, ethics, science and so on. A comprehensive consideration of these issues arises from the fact that often, in legal matters such as the legality of editing the genome of a viable embryo, the ethical aspect of the issue must be given priority.

Currently, most national jurisdictions are hindering scientific progress in genomics. The solution will be an international consensus reached by States and enshrined in an international treaty, based on the recognition of the international character of genomic research, the need to share the results of research between countries in order to develop science rather than to impose prohibitions.

The question of the delimitation of the object and subject in the editing of the genome can be solved by introducing legal criteria for delimitation. The combination of criteria such as individualization, passive capacity, active capacity and free will make it possible to distinguish between the object and the subject of various kinds of interventions in the human genome by defining clear boundaries for such interventions.

These criteria are specific to the subject of law, since:

1) the characteristics of individualization, such as first name, surname, patronymic, age, are specific to the subject;

2) passive capacity arises only from birth;

3) active capacity implies the exercise of subjective rights and legal obligations and requires the attainment of a certain age, as established by law;

4) a free will ensures that the subject participates in the legal relationship.

This will provide, in contentious legal situations, a definition of the subject matter of the legal relationship.

This delineation will also make it possible in the future to ensure an adequate level of protection of the rights and freedoms of the subjects of such legal relations, both at the international and national levels. In particular, in the protection of subjects of rights such as the right to life, the right to health and the right to security of a person. This distinction will make it possible to define a clear range of subjects entitled to judicial protection in the event of harm to health during the editing of the genome.

The study was carried out with the support of the grant obtained from the federal budget for the implementation of a scientific project entitled "Identification of problems of legal regulation in the use of genetic and genomic information. Preparation of scientifically based proposals to introduce changes in the system of the Russian legislation in order to eliminate them" (code topic: FEUW-2020-0005).

\section{References}

1. A. Boggio, B. M. Knoppers, J. Almqvist, C.P.R. Romano, The human right to science and the regulation of human germline engineering, The CRISPR Journal, 134-142 (2019)

2. Retrieved from: https://rm.coe.int/168007d004

3. Retrieved from: http://www.bioethics.ru/rus/res_eth/

4. N.V. Antonova, S.B. Balkhaeva, J.A. Gaunova, Legal concept of robotization: monograph (Prospekt, Moscow, 2019) 240 p.

5. A.A. Mokhov, A.N. Yavorsky, Genes and other gene-based entities as objects of intellectual property right, Civil law, 4, 28-32 (2018)

6. Retrieved from: https://nebula.org/blog/ru/днксеквенирование/

7. Retrieved from: https://docs.cntd.ru/document/ 901972162

8. S.S. Alexeyev, General theory of law. In two volumes. Volume 2. (Legal literature, Moscow, 1982) $360 \mathrm{p}$.

9. S.I. Arhipov, Subject of law: theoretical research (Publishing house R. Aslanov «Legal Center Press», Saint Petersburg, 2004) 469 p.

10. Retrieved from: http://www.consultant.ru/ document/cons_doc_LAW_5142/

11. E.V. Ponomareva, Subjects and quasi-subjects of law: Theoretical-legal problems of delimitation: candidate dissertation (Yekaterinburg, 2019) 208 p.

12. G.F. Shershenevich, Textbook of Russian Civil Law (Spark, Moscow, 1995) 556 p.

13. Federal Law of 21.11.2011 323-FL (Rev. of 22.12.2020) «On Fundamentals of Protection of Health of Citizens in the Russian Federation» (entered into force since 01.01.2021). «Legislative Assembly of the Russian Federation», 28.11.2011, 48, art. 6724.

14. ECHR. Parrillo v. Italy App. No. 46470/11, Judgment of 27 August 2015. Retrieved from: http://hudoc.echr.coe.int/eng?i=001-157263

15. ECHR. Evans v. the United Kingdom App. No. 6339/05, Judgment of 10 April 2007. Retrieved from: http://hudoc.echr.coe.int/eng? $\mathrm{i}=001-80046$

16. Retrieved from: http://hrlibrary.umn.edu/ russian/instree/Rzoas3con.html

17. Retrieved from: http://www.constitution.ru/ 10003000/10003000-4.htm

18. G. Hegel, Philosophy of Law (Yuryt Press, Moscow, 2020) $292 \mathrm{p}$. 